\title{
PROFIL KETERAMPILAN SOSIAL SISWA SMKS KESEHATAN UNAAHA BERDASARKAN JENIS KELAMIN SISWA
}

\author{
oleh: \\ DODI PRIYATMO SILONDAE \\ Dosen Jurusan Bimbingan dan Konseling, Fakultas Keguruan dan Ilmu Pendidikan \\ Universitas Halu Oleo \\ Email: dodi_silondae@uho.ac.id
}

\begin{abstract}
ABSTRAK
Tujuan penelitian ini untuk mengetahui perbedaan keterampilan sosial antara siswa lakilaki dan siswa perempuan di SMKS Kesehatan Unaaha tahun akademik 2012/2013. Populasi penelitian ini adalah seluruh siswa kelas X SMKS Kesehatan Unaaha sebanyak 74 orang yang tersebar pada 3 kelas. Pengambilan sampel menggunakan teknik total sampling dikarenakan jumlah populasi yang kurang dari 100 orang. Hipotesis penelitian adalah terdapat perbedaan keterampilan sosial antara siswa laki-laki dan siswa perempuan di SMKS Kesehatan Unaaha tahun akademik 2012/2013. Pengumpulan data dilakukan menggunakan skala keterampilan sosial. Data dianalisis menggunakan analisis statistik deskriptif persentase. Hasil penelitian menunjukkan bahwa secara umum siswa laki-laki di SMKS Kesehatan Unaaha pada tahun akademik 2012/2013 memiliki keterampilan sosial yang lebih baik dibandingkan siswa perempuan. Skor keterampilan sosial siswa laki-laki mayoritas berada dalam kategori Tinggi yakni sebanyak 16 orang atau sebesar 59,26\% sedangkan skor keterampilan sosial siswa perempuan mayoritas berada pada kategori Rendah yakni sebanyak 23 orang siswa atau sebesar $48,94 \%$.
\end{abstract}

Kata Kunci: Keterampilan Sosial, Siswa Laki-laki, Siswa Perempuan

\begin{abstract}
The purpose of this study was to determine the differences in social skills between male and female students in Unaaha Health Public Health School 2012/2013 academic year. The population of this study was all 74 students of Unaaha Health Elementary School X class, spread over 3 classes. Sampling uses a total sampling technique because the total population is less than 100 people. The research hypothesis is that there are differences in social skills between male and female students in Unaaha Health Public Health School 2012/2013 academic year. Data collection is done using the social skills scale. Data were analyzed using descriptive statistical analysis of percentages. The results showed that in general male students at the Unaaha Health Public Health School in the 2012/2013 academic year had better social skills than female students. The majority of the social skills scores of male students were in the High category of 16 people or $59.26 \%$ while the majority of the female social skills scores were in the Low category of 23 students or $48.94 \%$.
\end{abstract}

Keywords: Social Skills, Male Students, Female Students 


\section{PENDAHULUAN}

Sebagai individu yang berada dalam kategori remaja dalam rentang perkembangan manusia, siswa pada jenjang pendidikan sekolah menegah atas (SMA) atau sederajat juga mengalami berbagai gejolak psikologis sebagai konsekuensi pertumbuhan fisik serta perkembangan mental yang sedang terjadi pada diri mereka. Berbagai perubahan yang terjadi pada diri remaja tersebut memengaruhi hampir semua aspek kehidupan siswa dan terjadi secara signifikan mulai dari meningginya emosi, perubahan fisik yang sesuai atau tidak sesuai dengan apa yang mereka dambakan, perubahan nilai terhadap segala hal yang ada di sekelilingnya serta sikap plin-plan (ambivalen) terhadap tuntutan akan kebebasan serta ketakutan akan tanggung jawab (Hurlock, 2002).

Kondisi remaja tersebut sering diibaratkan sebaga "masa badai" sebagai gambaran betapa kritisnya setiap individu dalam menjalani masa remaja dalam kehidupannya, jika individu tidak mampu mengarahkan dirinya pda hal yang positif maka individu ada masa remaja akan sering terlibat dalam berbagai masalah baik yang merugikan dirinya sendiri maupun yang merugikan orang lain.

Beberapa persoalan yang melibatkan siswa SMA/ sederajat antara lain perilaku merundung (bullying) siswa yang lebih muda (junior) atau yang lebih lemah (Detik.com, 2012 dan Tempo.co, 2012), meningkatnya tawuran antar pelajar akibat ketersinggungan, harga diri serta solidaritas sesama almamater (Okezone.com, 2011 dan Kompas.com, 2011) hingga kasus pembunuhan karena cinta ditolak oleh perempuan yang disukainya (Detik.com, 2012).

Keterlibatan siswa terhadap berbagai masalah akan menempatkan mereka kepada persoalan-persoalan yang lebih rumit lagi seperti menerima skorsing dari sekolah, pemecatan atas statusnya sebagai siswa hingga ancaman masuk ke dalam jeruji besi jika sudah menyangkut pelanggaran hukum. Akan tetapi, yang jauh lebih berbahaya jika siswa terlibat dalam berbagai masalah adalah berkurangnya individu-individu terbaik bangsa pelaku pembangunan nasional di masa yang akan datang. Dengan demikian, permasalahan sosial yang dialami oleh siswa merupakan hal yang perlu menjadi perhatian serius bagi para penyelenggara pendidikan di sekolah.

Salah satu upaya yang $\begin{array}{r}\text { dapat } \\ \text { dilaksanakan sebagai }\end{array}$ bentuk
pencegahan terlibatnya siswa dalam
berbagai persoalan sosial adalah dengan
menanamkan keterampilan sosial
sebagai modal dalam menjalani
berbagai bentuk relasi sosial dalam
kehidupannya. Keterampilan sosial
dapat dimaknai sebagai sebuah
keterampilan yang digunakan oleh
individu dalam menjalankan peran
sosial yang dijalaninya agar hubungan
sosial individu tersebut dapat menjadi
adaptif dan produktif dalam mencapai
tujuan sosialnya.

Meningkatkan keterampilan sosial siswa sebagai salah satu cara menghindarkan siswa terhadap berbagai permasalahan sosial selaras dengan apa yang mejadi tugas perkembangan mereka saat ini dan nanti yang lebih menuntut setiap individu bergeser dari makhluk individual menjadi makhluk sosial. Beberapa tugas perkembangan masa remaja seperti mencapai hubungan 
baru yang lebih matang dengan teman sebaya, mencapai peran sosial yang matang, mempersiapkan karir serta pernikahan serta kemampuan betingkah laku sosial dan bertanggung jawab (Havighurst dalam Santrock, 2007) akan mudah pencapaiannya jika dalam diri siswa memiliki keterampilan sosial yang tinggi.

Dengan demikian, kondisi keterampilan sosial yang dimiliki oleh siswa di setiap satuan pendidikan adalah data yang perlu dimiliki demi memudahkan upaya sekolah dalam merumuskan berbagai macam program pendidikan yang dapat menghindarkan siswa dalam berbagai masalah sosial.

Dalam menyusun informasi mengenai kondisi keterampilan sosial siswa, data yang telah dikumpulkan dapat disortir ke dalam berbagai bentuk varian pendekatan, salah satunya adalah berdasarkan jenis kelamin siswa. Pemilahan informasi keterampilan sosial siswa berdasarkan jenis kelamin menjadi penting karena begitu banyak karakteristik spesifik individu yang menjadi berbeda ketika ditinjau dari aspek jenis kelaminnya. Selain itu, pemilahan tersebut akan memudahkan pihak sekolah khususnya guru bimbingan dan konseling dalam memahami kondisi peserta didik secara lebih rinci.

\section{Pengertian Keterampilan Sosial}

Upaya memahami makna dari keterampilan sosial telah dilakukan oleh beberapa ahli dengan cara merumuskan pengertian dari keterampilan sosial. Widoyoko (2011) menjelaskan bahwa keterampilan sosial (social skill) adalah sebuah keterampilan yang dibutuhkan oleh individu untuk hidup (life skill) dalam lingkungan masyarakat yang multikultur, masyarakat demokrasi dan masyarakat global yang penuh dengan persaingan dan tantangan.

Selanjutnya, Menurut Sjamsuddin dan Maryani (2008) mendefiniskan keterampilan sosial sebagai suatu kemampuan individu yang ditampilkan secara cakap dalam tindakan, mencari, memilah dan mengelola informasi, mempelajari berbagai hal yang dapat memecahkan masalah sehari-hari, memiliki keterampilan berkomunikasi yang baik secara lisan maupun tulisan, memahami, menghargai dan mampu bekerjasama dengan orang lain yang majemuk, mampu mentransformasikan kemampuan akademik dan beradaptasi dengan perkembangan masyarakat.

Definisi yang disajikan oleh para ahli tersebut menunjukkan bahwa keterampilan sosial merupakan kemampuan yang ada dalam diri individu, yang dengan keterampilan tersebut mampu menjadikan individu menjalani kehidupannya sebagai makhluk sosial secara dinamis dan produktif serta mampu adaptif terhadap berbagai kondisi masyarakat di lingkungan tempat tinggalnya.

\section{Aspek-aspek Keterampilan Sosial}

Keterampilan sosial merupakan akumulasi kemampuan individu dalam menampilkan perilaku dalam berbagai aspek kehidupannya dan melalui perilaku tersebut, individu dapat menjalani kehidupan sosialnya dengan adaptif dan produktif. Stephen (dalam William, 2012: 59-74) menyebutkan 4 (empat) aspek perilaku individu yang menjadi gambaran keterampilan sosialnya, yakni:

1. Self-related behavior, yakni perilaku sosial individu yang muncul karena 
terdapat berbagai pertimbangan serta penghayatan di dalam dirinya seperti: 1) memiliki dan menjaga sikap etis, 2) kemampuan mengekspresikan perasaan, 3) bersikap positif terhadap diri sendiri, dan 4) menerima konsekuensi terhadap hal-hal yang telah dilakukan.

2. Enviromental behavior yakni perilaku sosial individu yang muncul karena pengaruh orang-orang serta nilai atau norma berlaku di lingkungan tersebut, seperti: 1) kemampuan menyesuaikan diri, 2) kemampuan menjaga kelestarian lingkungan, dan 3) kememapuan menerima dan beradaptasi terhadap situasi dan kondisi keadaan yang bersifat tiba-tiba.

3. Task-related behavior yakni perilaku sosial individu yang muncul karena tuntutan dan kewajiban yang harus dilakukannya sesuai dengan peran yang sedang dijalaninya. Misalnya peserta didik, task-related behavior pada mereka antara lain: 1) mengerjakan tugas mata pelajaran, 2) memiliki kebiasaan belajar yang baik, 3) aktif dalam proses pembelajaran di kelas serta 4) memerhatikan guru selama menjelaskan materi pelajaran.

4. Interpersonal behaviors yakni perilaku sosial individu terkait dengan relasinya dengan orang lain di lingkungannya seperti: 1) menerima aturan dalam kelompok sosial, 2) memberikan simpati serta empati kepada teman sebayanya, 3) terlibat aktif dalam kegiatan kelompok serta 4) mampu menghargai privasi orang lain.

Pendapat lain dikemukakan oleh Maryani (2011: 20) yang menyebutkan bahwa keterampilan sosial individu dapat dikelompokkan ke dalam 4 (empat) keterampilan di mana antara satu keterampilan dengan keterampilan lainnya saling berkaitan sehingga membentuk sebuah keterampilan baru yakni keterampilan sosial. Keempat keterampilan tersebut adalah:

1. Keterampilan dasar berinteraksi: berusaha untuk saling mengenal, ada kontak mata, berbagai informasi atau material.

2. Keterampilan komunikasi: mendengar dan berbicara secara bergiliran, melembutkan suara (tidak membentak), menyakinkan orang untuk mengemukakan pendapat, mendengarkan sampai orang tersebut menyelesaikan pembicaraannya.

3. Keterampilan membangun tim/ kelompok: mengakomodasi pendapat orang, bekerjasama, saling menolong dan saling memerhatikan, dan

4. Keterampilan menyelesaikan masalah: mengendalikan diri, empati, memikirkan orang lain, taat terhadap kesepakatan, mencari jalan keluar dengan berdiskusi, respek terhadap pendapat yang berbeda

\section{Ciri-ciri Keterampilan Sosial}

Keberadaan keterampilan sosial setiap individu akan nampak dalam pergaulan sosial yang dijalaninya di lingkungan di mana dia berada. Individu yang memiliki keterampilan sosial yang baik akan mampu mengembangkan kehidupan sosial yang positif, produktif dan dinamis baik dalam menjalani relasi dengan dirinya sendiri maupun dalam menjalani relasi orang lain. Hal ini selaras dengan pendapat yang disampaikan oleh Elksnin dan Elksnin (dalam Hertinjung, dkk, 2008) yang mengidentifikasi beberapa aktifitas perilaku individu yang dapat dijadikan patron dari keberadaan serta tinggi 
rendahnya keterampilan sosial bagi setiap individu, yaitu:

1. Perilaku interpersonal, yakni segala bentuk perilaku yang ditampakkan oleh individu selama dia menjalin relasi dengan orang lain, salah satunya adalah relasi persahabatan yang dijalin oleh individu tersebut.

2. Perilaku intrapersonal (perilaku yang berhubungan dengan diri sendiri), yakni perilaku yang ditampilkan individu terhadap dirinya sendiri dalam situasi sosial yang dijalaninya.

3. Perilaku akademik (academic achievement), yakni perilaku yang ditampilkan oleh individu yang mampu mendukung tercapainya kesuksesan akademiknya.

4. Penerimaan teman sebaya (peer acceptance) yakni segala perilaku yang ditampilkan oleh individu yang mampu diterima atau disetujui oleh teman-teman pergaulannya.

5. Keterampilan komunikasi, yakni perilaku yang ditampilkan oleh individu dalam menyampaikan pesan-pesan baik verbal maupun nonverbal kepada lawan bicaranya.

\section{Faktor-faktor yang Memengaruhi Keterampilan Sosial}

Sebagaimana pada aspek-aspek perilaku individu yang lainnya, keterampilan sosial yang dimiliki oleh setiap individu dipengaruhi oleh dua faktor utama, yakni faktor internal serta faktor eksternal kehidupannya. Cartledge dan Milburn (1995) juga merumuskan 2 faktor yang memengaruhi tinggi rendahnya keterampilan sosial individu datang dari dalam dirinya (karakteristik individu) serta yang datang dari luar dirinya (kriteria lingkungan sosial individu).

1. Karakteristik Individu

Beberapa hal dalam karakteristik individu yang memengaruhi keterampilan sosial antara lain: 1) tingkat perkembangan, 2) jenis kelamin, 3) kemampuan kognitif dan 4) perilaku.

2. Kriteria Lingkungan sosial individu

Beberapa hal dalam kriteria lingkungan sosial individu yang memengaruhi keterampilan sosial antara lain: 1) konteks budaya dimana individu dibesarkan, 2) situasi spesifik seperti fleksibilitas perilaku serta 3) pola pertemanan sebaya yang dijalani oleh individu tersebut.

\section{METODE PENELITIAN}

\section{Lokasi dan Waktu Penelitian}

Penelitian ini dilaksanakan di Sekolah Menengah Kejuruan Swasta (SMKS) Kesehatan Unaaha yang beralamat di Jalan Edy Sabara Nomor 439 Kelurahan Asinua Kecamatan Unaaha Kabupaten Konawe Provinsi Sulawesi Tenggara. Penelitian ini dilaksanakan pada tahun akademik 2012/2013.

\section{Jenis Penelitian}

Penelitian ini merupakan penelitian komparatif dengan pendekatan deskriptif, yakni penelitian yang bersifat membandingkan dua variabel atau lebih (Sugiyono, 2012). Penelitian ini bermaksud untuk memberikan gambaran perbandingan keterampilan sosial yang dimiliki oleh siswa laki-laki dan siswa perempuan di SMKS Kesehatan Unaaha. 


\section{Populasi dan Sampel Penelitian}

\section{Populasi}

Populasi dalam penelitian ini adalah seluruh siswa kelas X SMKS Kesehatan Unaaha yang terdaftar pada tahun akademik 2012/2013. Populasi dalam penelitian ini berjumlah 74 orang yang tersebar ke dalam 3 (tiga) kelas yakni X Perawat 1, X Perawat 2 dan X Farmasi.

\section{Sampel}

Sampel dalam penelitian ini diambil menggunakan teknik total sampling dengan mengacu pada pendapat Arikunto (1998) bahwa jika populasi penelitian kurang dari 100 maka seluruh populasi tersebut akan dijadikan sampel sedangkan jika populasi penelitian lebih dari 100 maka sampel yang diambil adalah $10-15 \%$ atau $20-25 \%$ dari total populasi.

Gambaran sampel dalam penelitian ini dapat dilihat melalui tabel berikut:

Tabel 1. Rincian Sampel Penelitian

\begin{tabular}{|c|c|c|c|}
\hline \multirow{2}{*}{ No } & \multirow{2}{*}{ Kelas } & \multicolumn{2}{|c|}{ Sampel } \\
\cline { 3 - 4 } & & Laki-laki & Perempuan \\
\hline 1 & X Perawat 1 & 8 & 17 \\
\hline 2 & X Perawat 2 & 9 & 19 \\
\hline 3 & X Farmasi & 10 & 11 \\
\hline \multicolumn{2}{|c|}{ Jumlah Sampel } & $\mathbf{2 7}$ & $\mathbf{4 7}$ \\
\hline
\end{tabular}

\section{Metode Pengumpulan Data}

Data dalam penelitian ini dikumpulkan menggunakan skala keterampilan sosial yang dikembangkan dari indikator keterampilan menurut Stephen (dalam William, 2012) yang terdiri dari 1) Selfrelated behavior, 2) Enviromental behavior, 3) Task-related behavior dan 4) Interpersonal behaviors. Skala keterampilan sosial yang disusun terdiri dari 4 pilihan jawaban yakni: SS (Sangat Sesuai), S (Sesuai), TS (Tidak Sesuai) dan STS (Sangat Tidak Sesuai).

\section{Teknik Analisis Data}

Data yang telah diperoleh melalui penyebaran skala keterampilan sosial selanjutnya akan dianalisis menggunakan teknik analisis data deskriptif persentase. Anaslisis data deskriptif persentase digunakan untuk menggambarkan distribusi skor responden masing-masing variabel yaitu, nilai maksimum dan nilai minimum, modus, mean, persentase serta kategori. Dalam menggambarkan data tingkat keterampilan sosial siswa mengacu pada tabel berikut:

Tabel 2. Kategorisasi Skor Interval Frekuensi

\begin{tabular}{|l|c|}
\hline \multicolumn{1}{|c|}{ Kategori } & $\begin{array}{c}\text { Skor Interval } \\
\text { Frekuensi }\end{array}$ \\
\hline Sangat Rendah & $43-75$ \\
\hline Rendah & $76-108$ \\
\hline Tinggi & $109-141$ \\
\hline Sangat Tinggi & $142-172$ \\
\hline
\end{tabular}

\section{HASIL PENELITIAN DAN PEMBAHASAN}

\section{Hasil Penelitian}

Hasil analisis terhadap data keterampilan sosial sosial siswa SMKS 
Kesehatan Unaaha yang dikumpulkan menggunakan skala keterampilan sosial siswa selanjutnya dipilah berdasarkan jenis kelamin (gender) siswa sehingga dapat ditabulasikan ke dalam tabel berikut:

Tabel 3. Skor Keterampilan Siswa Lakilaki

\begin{tabular}{|c|c|c|c|c|c|}
\hline SAMPEL & SKOR & KATEG0RI & SAMPEL & SK0R & KATEG0RI \\
\hline S01 & 108 & RENDAH & S16 & 117 & TINGGI \\
\hline $\mathrm{S} 02$ & 138 & TINGGI & S17 & 91 & RENDAH \\
\hline S03 & 121 & TINGGI & S18 & 109 & TINGGI \\
\hline S04 & 104 & RENDAH & S19 & 108 & RENDAH \\
\hline S05 & 153 & SANGAT TINGGI & S20 & 104 & RENDAH \\
\hline S06 & 134 & TINGGI & S21 & 108 & RENDAH \\
\hline S07 & 116 & TINGGI & S22 & 109 & TINGGI \\
\hline S08 & 121 & TINGGI & S23 & 134 & TINGGI \\
\hline S09 & 111 & TINGGI & S24 & 146 & SANGAT TINGGI \\
\hline $\mathrm{S} 10$ & 134 & TINGGI & S25 & 75 & SANGAT RENDAH \\
\hline S11 & 119 & TINGGI & $\$ 26$ & 112 & TINGGI \\
\hline S12 & 115 & TINGGI & S27 & 132 & TINGGI \\
\hline$S 13$ & 109 & TINGGI & & & \\
\hline S14 & 103 & RENDAH & & & \\
\hline S15 & 103 & RENDAH & & & \\
\hline
\end{tabular}

Berdasarkan data pada tabel 3 di atas, nampak bahwa skor maksimum adalah 153, skor minimum adalah 75 dengan terdapat tiga skor sebagai modus yakni 108, 109 dan 134 sedangkan mean sebesar 116,07.

Secara umum, keterampilan sosial siswa laki-laki di kelas X SMKS Kesehatan Unaaha berada dalam kategori Tinggi, hal ini merujuk pada pada jumlah sampel yang berada pada kategori tersebut yakni sebanyak 16 orang atau sebesar 59,26\%. Siswa yang berada pada kategori Sangat Rendah hanya sebanyak 1 orang atau sebesar $3,70 \%$, kategori Rendah sebanyak 8 orang atau sebesar $29,63 \%$ dan kategori Sangat Tinggi hanya sebanyak 2 orang atau sebesar $7,41 \%$.
Tabel 4. Skor Keterampilan Siswa Perempuan

\begin{tabular}{|c|c|c|c|c|c|}
\hline SAMPEL & SKOR & KATEGORI & SAMPEL & SKOR & KATEGORI \\
\hline S01 & 94 & RENDAH & S26 & 104 & RENDAH \\
\hline S02 & 106 & RENDAH & S27 & 161 & SANGAT TINGGI \\
\hline S03 & 125 & TINGGI & S28 & 139 & TINGGI \\
\hline S04 & 139 & TINGGI & S29 & 136 & TINGGI \\
\hline S05 & 98 & RENDAH & S30 & 133 & TINGGI \\
\hline S06 & 96 & RENDAH & S31 & 135 & TINGGI \\
\hline S07 & 117 & TINGGI & S32 & 83 & RENDAH \\
\hline S08 & 138 & TINGGI & S33 & 94 & RENDAH \\
\hline S09 & 121 & TINGGI & S34 & 91 & RENDAH \\
\hline S10 & 119 & TINGGI & S35 & 88 & RENDAH \\
\hline S11 & 106 & RENDAH & S36 & 122 & TINGGI \\
\hline S12 & 116 & TINGGI & S37 & 91 & RENDAH \\
\hline S13 & 112 & TINGGI & S38 & 117 & TINGGI \\
\hline S14 & 115 & TINGGI & S39 & 121 & TINGGI \\
\hline S15 & 110 & TINGGI & S40 & 102 & RENDAH \\
\hline S16 & 120 & TINGGI & S41 & 71 & SANGAT RENDAH \\
\hline S17 & 107 & RENDAH & S42 & 84 & RENDAH \\
\hline S18 & 137 & TINGGI & S43 & 92 & RENDAH \\
\hline S19 & 123 & TINGGI & S44 & 165 & SANGAT TINGGI \\
\hline S20 & 105 & RENDAH & S45 & 95 & RENDAH \\
\hline S21 & 108 & RENDAH & S46 & 84 & RENDAH \\
\hline S22 & 113 & TINGGI & S47 & 91 & RENDAH \\
\hline S23 & 96 & RENDAH & & & \\
\hline S24 & 99 & RENDAH & & & \\
\hline S25 & 99 & RENDAH & & & \\
\cline { 1 - 2 } & & & & \\
\hline
\end{tabular}

Berdasarkan data yang tersaji pada tabel 4 di atas nampak bahwa skor maksimum adalah 165 , skor minimum adalah 71 dengan skor 91 sebagai modus dan mean sebesar 111,02.

Secara umum, skor keterampilan sosial siswa perempuan di kelas $\mathrm{X}$ SMKS Kesehatan Unaaha paling banyak tersebar pada dua kategori yakni kategori Rendah sebanyak 23 orang siswa atau sebesar $48,94 \%$ dari total sampel dan pada kategori Tinggi yakni sebanyak 21 orang siswa atau sebanyak $44,68 \%$ dari total sampel. Jumlah sampel yang berada pada kategori Sangat Rendah dan kategori Sangat Tinggi berada pada jumlah yang tidak signifikan yakni hanya 1 orang siswa berada pada kategori Sangat rendah atau sebesar $2,13 \%$ dan hanya 2 orang siswa yang berada pada kategori Sangat Tinggi atau sebesar $4,26 \%$. 


\section{Pembahasan}

Hasil penelitian menunjukkan bahwa secara umum keterampilan sosial siswa laki laki lebih baik dibandingkan dengan siswa perempuan. Siswa lakilaki yang memiliki skor keterampilan sosial yang baik secara keseluruhan adalah sebanyak 18 orang atau sebesar $66,67 \%$ yang terdiri dari 16 siswa berada pada kategori Tinggi dan 2 orang siswa berada pada kategori Sangat Tinggi. Untuk siswa perempuan secara keseluruhan, siswa yang memiliki keterampilan sosial yang baik adalah sebanyak 23 orang siswa atau sebanyak $48,93 \%$ yang terdiri dari 21 orang berada pada kategori Tinggi dan 2 orang siswa berada pada kategori Sangat Tinggi.

Adanya perbedaan terhadap skor keterampilan sosial siswa Kelas $\mathrm{X}$ SMKS Kesehatan Unaaha jika ditinjau dari perbedaan jenis kelamin merupakan sesuatu yang umum terjadi karena banyak aspek psikologis dalam diri individu ditentukan oleh jenis kelamin individu tersebut, termasuk perihal keterampilan sosial (Cartledge dan Milburn, 1995).

Hasil penelitian ini sesuai dengan beberapa studi yang telah dilakukan sebelumnya yang menggambarkan bahwa terdapat beberapa perbedaan pada diri individu jika ditinjau dari aspek jenis kelaminnya seperti pada cara memersepsi sesuatu (Iriyanto dan Winaryati, 2010), pada cara belajar dan prestasi belajar (Zurliani, 2010), kemampuan berhitung matematika menggunakan otak kanan (Purwanti, 2013) hingga pada kompetensi berbicara (Ratminingsih, 2013).
Keberadaan data mengenai profil keterampilan sosial siswa di SMKS Kesehatan Unaaha merupakan instrumen pendukung pihak sekolah dalam menentukan berbagai kebijakan sekolah terkait dengan upaya menghindarkan siswa dari berbagai permasalahan sosial yang mungkin dialami mereka. Layanan bimbingan dan konseling (BK) sebagai salah satu entitas personil pendidikan di sekolah merupakan pihak yang tepat dalam merespon kondisi keterampilan sosial tersebut karena sesuai dengan fungsi keberadaan mereka di sekolah sebagai layanan yang berupaya untuk mencegah siswa terlibat dalam masalah, memelihara serta mengembangkan potensi siswa agar tidak terlibat dalam suatu masalah hingga mengentaskan siswa yang telah terlibat dalam suatu masalah.

Upaya meningkatkan keterampilan sosial siswa dapat dilakukan oleh guru bimbingan dan konseling dengan memanfaatkan berbagai jenis layanan $\mathrm{BK}$, kegiatan pendukung $\mathrm{BK}$ hingga berbagai bentuk kolaborasi dengan pihak lainnya. Beberapa jenis layanan yang dapat diberikan antara lain layanan informasi serta bimbingan kelompok sebagai upaya pencegahan, pelaksanaan konseling individu maupun kelompok sebagai bentuk pengentasan dan juga kunjungan rumah sebagai salah satu cara menjalin kolaborasi dengan orang tua siswa.

Salah satu bentuk kolaborassi guru BK dalam meningkatkan keterampilan sosial siswa adalah dengan mengaktifkan serta memaksimalkan program konselor sebaya. Pelaksanaan program konselor sebaya ini dapat dilaksanakan dengan memilih beberapa siswa yang potensial 
yang memiliki keterampilan sosial tinggi, kemampuan komunikasi yang mumpuni baik verbal maupun non verbal serta jiwa kepemimpinan yang tinggi sebagai konselor sebaya untuk membimbing teman sejawat mereka yang memiliki keterampilan sosial yang kurang.

Pelaksanaan program konselor sebaya ini dapat memberikan dampak yang cukup signifikan mengingat karakteristik siswa di tingkat SMA/ sederajat sebagai remaja yang akan lebih mudah untuk bersikap terbuka serta menjalin kerjasama dengan individu yang sepantaran dengan mereka secara usia.

\section{KESIMPULAN DAN SARAN}

\section{Kesimpulan}

Berdasarkan hasil analisis terhadap data penelitian, terlihat bahwa secara umum siswa laki-laki di SMKS Kesehatan Unaaha pada tahun akademik 2012/2013 memiliki keterampilan sosial yang lebih baik dibandingkan siswa perempuan. Skor keterampilan sosial siswa laki-laki mayoritas berada dalam kategori Tinggi yakni sebanyak 16 orang atau sebesar 59,26\% sedangkan skor keterampilan sosial siswa perempuan mayoritas berada pada kategori Rendah yakni sebanyak 23 orang siswa atau sebesar 48,94\%.

\section{Saran}

Beberapa saran yang timbul berdasarkan hasil penelitian ini antara lain sebagai berikut:

1. Adanya siswa yang memiliki keterampilan sosial yang rendah perlu mendapatkan perhatian serius bagi seluruh personil pendidikan di sekolah agar menghindarkan siswa pada berbagai masalah yang dapat merugikan siswa, sekolah dan masyarakat.

2. Upaya meningkatkan keterampilan sosial siswa dapat dilakukan dengan cara memaksimalkan peran konselor sebaya, mengingat karakteristik remaja yang lebih terbuka kepada teman yang sepantaran dengan mereka.

3. Guru bimbingan konseling perlu menindaklanjuti informasi mengenai siswa yang memiliki keterampilan sosial rendah dengan memberikan layanan bimbingan dan konseling serta menjalin kerjasama dengan orang tua/ wali siswa tersebut.

\section{DAFTAR PUSTAKA}

Cartledge, G. \& Millburn, J. F. 1995. Teaching Social Skills to Children \&Youth. Innovative Aproach, 3rd ed. Massachussets: Allyn \& Bacon.

Detik.com. 2012.

https://news.detik.com/berita/d1979089/5-kasus-bullying-smadi-jakarta/2

Hertinjung, Wisnu Sri. 2008. Keterampilan Sosial Anak Pra Sekolah Ditinjau dari Interaksi Guru-Siswa Model Mediated Learning Experience. Journal Penelitian Humaniora, 9 (2)

Hurlock, Elizabeth B. (2002). Psikologi Perkembangan, Suatu Pendekatan Sepanjang Rentang Kehidupan, Edisi Kelima (alih bahasa). Jakarta: Erlangga. 
Iriyanto, Setia dan Eny Winaryati. 2010. Perbedaan Persepsi Antar Jenis Kelamin Terhadap Peran Gender Dalam Keluarga Dan Masyarakat: Antara Harapan dan Kenyataan pada Guru-guru SD di Wilayah Kecamatan Tembalang Kota Semarang. https://jurnal.unimus.ac.id/index.p hp/psn12012010/article/download /67/39

Kompas.com.

2011.

https://regional.kompas.com/read/ 2011/10/21/02385365/twitt?page= all

Maryani, Enok. 2008. Pengembangan Program Pembelajaran IPS Untuk Meningkatkan Kompetensi Keterampilan Sosial. Bandung: Alfabeta.

Okezone.com.

2011.

https://news.okezone.com/read/20 11/04/22/340/449003/tawuranpelajar-di-yogyakarta-satu-orangtewas

Purwanti, Kristi Liani. 2013. Perbedaan Gender Terhadap Kemampuan Berhitung Matematika Menggunakan Otak Kanan Pada Siswa Kelas I. Jurnal Sawwa, Jurnal Studi Gender Vol. 9 No. 1. Hal. 107-122

Ratminingsih, Ni Made. 2013. Pengaruh Gender Dan Tipe Kepribadian Terhadap Kompetensi Berbicara Bahasa Inggris. https://ejournal.undiksha.ac.id/ind ex.php/JPP/article/viewFile/4230/ 3301

Santrock, John, W. 2007. Child Development, $11^{\text {th }}$ Edition (Terjemahan Mila Rahmawati dan Anna Kusumawati) Jakarta: Erlangga.

Sjamsuddin, Helius dan Enok Maryani, 2008. Pengembangan Program Pembelajaran IPS Untuk Meningkatkan Kompetensi Keterampilan Sosial (Jurnal Penelitian Vol.9 No. 1).

Sugiyono. 2012. Metode Penelitian Kuantitatif Kualitatif dan R\&D. Bandung: Alfabeta.

Tempo.co. 2012. https://metro.tempo.co/read/41978 6/begini-kronologi-bullying-di$\underline{\text { sma-don-bosco/full\&view=ok }}$

Widoyoko, Eko Putro. (2011). Evaluasi Program Pembelajaran Panduan Praktis bagi Pendidik dan Calon Pendidik. Yogyakarta: Pustaka Pelajar.

Williams, A.C. (2012). Mentoring and Social Skills Training: Ensuring Better Outcomes for Youth in Foster Care.Child Welfare Journal Vol. 90, No. 1. Hal. 5974.

Zurliani. 2010. Perbandingan Cara Belajar Dan Prestasi Belajar Siswa Laki-Laki Dengan Siswa Perempuan Pada Pondok Pesantren Anshorullah Desa Pulau Birandang Kecamatan Kampar Timur Kabupaten Kampar. Skripsi. Universitas Islam Negeri Sultan Syarif Kasim Riau. 